\title{
The effects of methylene blue on adhesion formation in a rat model of experimental peritonitis
}

Deneysel peritonit modelinde metilen mavisinin adezyon formasyonu üzerine etkileri

\author{
Mustafa Uygar KALAYCI, ${ }^{1}$ Hasan Erol EROĞLU, ${ }^{2}$ Dilek KUBİLAY, ${ }^{3}$ Aliye SOYLU, ${ }^{4}$ \\ Banu SANCAK, ${ }^{5}$ Ceyhan UĞURLUOĞLU, ${ }^{6}$ Uğur ERÇiN,,${ }^{5}$ Yavuz Savaş KOCA ${ }^{2}$
}

\section{BACKGROUND}

We investigated the effects of methylene blue (MB) on the early and late phases of adhesion and abscess formation in a standard colonic wall injury and fecal peritonitis model in rats.

\section{METHODS}

There were four groups: Group I (only laparotomy, $n=10$ ), Group II (peritonitis $+\mathrm{MB}, \mathrm{n}=15$ ), Group III (peritonitis + saline, $\mathrm{n}=15$ ), and Group IV (colon incision + saline, $\mathrm{n}=15$ ). Mortality, morbidity, adhesion scores, histopathologic analyses, serum tumor necrosis factor-alpha (TNF- $\alpha$ ) levels, and tissue hydroxyproline (5-HP) levels were evaluated in all animals. Descriptive statistical methods were used with Kruskal-Wallis test. When a statistical difference was obtained between groups, Mann-Whitney U test was used to confirm the difference between two groups.

\section{RESULTS}

Adhesion scores of Groups I, III and IV were significantly higher than in Group II. TNF- $\alpha$ levels were significantly higher in Groups I, III and IV. 5-HP levels were significantly lower in Groups I and II compared to Groups III and IV.

\section{CONCLUSION}

Based on these results, it appears that MB may prevent peritoneal adhesions in a peritonitis model, but wound healing could be impaired. MB should be further evaluated because of its dual effect.

Key Words: Adhesion; methylene blue; peritonitis.

\section{$\boldsymbol{A M A C}$}

Sıçanlarda oluşturulan kolon duvar hasarı ve fekal peritonit modelinde metilen mavisinin (MM) erken ve geç dönemde adezyon ve apse oluşumu üzerine etkileri incelendi.

\section{GEREÇ VE YÖNTEM}

Çalışmada dört grup vardı; Grup I (yalnızca laparotomi, $\mathrm{n}=10$ ), Grup II (peritonit ve MM, n=15), Grup III (kolon insizyonu ve salin, $n=15$ ) ve Grup IV (kolon insizyonu ve salin, $n=15)$. Tüm deneklerde mortalite, morbidite, adezyon skorları, histopatolojik analiz, serum tümör nekroz faktörü- $\alpha$ (TNF- $\alpha$ ) ve doku hidroksiprolin (5-HP) düzeyleri değerlendirildi. Tanımlayıcı istatistiksel analiz Kruskal Wallis testi ile, istatistiksel anlamlılık saptandığında ise gruplar arasındaki fark Mann-Whitney U testi ile analiz edildi.

\section{BULGULAR}

Grup I, Grup III ve Grup IV'ün adezyon skorları Grup II'ye göre anlamlı yüksekti. TNF- $\alpha$ düzeyleri ise Grup I, Grup III ve Grup IV'de yüksek bulundu. 5-HP düzeyleri Grup I ve Grup II'de Grup III ve Grup IV'e göre düşüktü.

\section{SONUC}

MM'nin peritonit modelinde peritoneal adezyonları önlediği, ancak yara iyileşmesini olumsuz etkilediği söylenebilir. Bu ikili karşıt etkinin daha fazla araştırılması gerekir.

Anahtar Sözcükler: Adezyon; metilen mavisi; peritonit.

\footnotetext{
${ }^{1}$ Dept. of General Surgery, Okmeydani Training and Research Hospital, Istanbul; ${ }^{2}$ Dept. of General Surgery, Suleyman Demirel University, Faculty of Medicine, Isparta; ${ }^{3}$ Dept. of Medical Biochemistry, Dr. Abdurrahman Yurtarslan Training and Research Hospital, Ankara; ${ }^{4}$ Dept. of Gastroenterology, Bakirkoy Dr. Sadi Konuk Training and Research Hospital, Istanbul; ${ }^{5}$ Dept. of Medical Biochemistry, Gazi University Faculty of Medicine, Ankara; ${ }^{6}$ Dept. of Pathology, Dr. Faruk Sukan Children Hospital, Konya, Turkey.

${ }^{1}$ Okmeydanı Eğitim ve Araştırma Hastanesi, Genel Cerrahi Kliniği, İstanbul; ${ }^{2}$ Süleyman Demirel Üniversitesi Tıp Fakültesi, Genel Cerrahi Anabilim Dalı, Isparta; ${ }^{3} \mathrm{Dr}$. Abdurrahman Yurtaslan Eğitim ve Araştırma Hastanesi, Biyokimya Bölümü, Ankara; ${ }^{4}$ Bakırköy Dr. Sadi Konuk Eğitim ve Arastırma Hastanesi, Gastroenteroloji Kliniği, İstanbul; ${ }^{5}$ Gazi Üniversitesi Tip Fakültesi, Klinik Biyokimya Anabilim Dalı, Ankara; ${ }^{6}$ Dr. Faruk Sükan Cocuk Hastanesi, Patoloji Bölümü, Konya.
} 
Adhesion formation is a major complication in surgery. ${ }^{[1,2]}$ It has been estimated that the annual healthcare costs associated with adhesiolysis procedures amount to more than 1 billion USD in the United States. ${ }^{[3]}$ After colon surgery, the readmission rate due to adhesions is about $5-15 \% \cdot{ }^{[4]}$ Adhesion-related mortality reaches up to $15 \%$, and inadvertent enterotomy at a desiotomy occurs in 19\% in additional operations. ${ }^{[5]}$ Indeed, the rate of residual infection after peritonitis can be as high as 50\%, necessitating abdominal re-exploration or percutaneous abscess drainage in adhesions. ${ }^{[5,6]}$ Multiple factors have been associated with this problem, such as poor surgical technique, damage to the serosal surface of the intestinal wall, powder of gloves, type of suture material, devitalized tissue, pelvic inflammatory disease, cholecystitis, and appendicitis. ${ }^{[7,8]}$

Although several materials have been used to avoid adhesion formation in elective surgery, there are insufficient data on this issue in the case of peritonitis. Experimental data show that the use of antiadhesive agents in peritonitis reduces adhesions and abscesses and related mortality. ${ }^{[9,10]}$ To avoid adhesion formation in peritonitis, tenoxicam, aminoguanidine, beta glucan, polysaccharide carboxy methyl cellulose and phlennium saprophyte have been used in different studies. ${ }^{[11-14]}$

Adhesion formation is associated with significant oxidative stress, both from the activation of the mesothelium and underlying endothelial cells and, more importantly, from the infiltration and subsequent activation of neutrophils and macrophages and cytokines. ${ }^{[15-17]}$ Methylene blue (MB) acts as an antioxidant and may reduce intraabdominal nascent fibrinous adhesions, and is rapidly degraded via intraabdominal proteases such as tissue plasminogen activator (tPA), which is a major component of the peritoneal fibrinolytic system. ${ }^{[16]} \mathrm{MB}$ was defined as an effective agent to avoid the permanent fibrous adhesion formation in peritoneal trauma due to antioxidant activity. ${ }^{[18]}$

Based on the literature concerning the antiadhesive properties of $\mathrm{MB}$, the present study was designed to investigate the effects of MB on the early and late phases of adhesion and wound healing in an experimental colonic wall injury and fecal peritonitis model in rats.

\section{MATERIALS AND METHODS}

\section{Animals}

Female Wistar-Albino rats $(225-280$ g) were housed in an air-conditioned room at a constant temperature of $22 \pm 2^{\circ} \mathrm{C}$ with $12: 12 \mathrm{~h}$ light/dark cycle and fed a standard diet and water ad libitum. The animals were acclimatized for one week before the experiments. Only water was provided in the 12 hours pre- ceding the experiments. The experimental protocol was approved by the Suleyman Dermirel University Faculty of Medicine Animal Care and Use Committee.

\section{Experimental Groups}

Rats were divided into four groups including laparotomy (Group I; $\mathrm{n}=10$ ), peritonitis+MB (Group II; $\mathrm{n}=15$ ), peritonitis + saline (Group III; $\mathrm{n}=15$ ), and colon incision+saline (Group IV; n=15) groups. Mortality, morbidity, adhesion scores, bacterial analysis, histopathologic analysis, tissue hydroxyproline (5-HP), and plasma tumor necrosis factor-alpha (TNF- $\alpha$ ) level were taken as control parameters.

\section{Surgical Operations}

The animals were weighed and anesthetized with intramuscular (im) ketamine $(50 \mathrm{mg} / \mathrm{kg})$ and xylazine $(6 \mathrm{mg} / \mathrm{kg})$. The abdominal skin was disinfected with $70 \%$ Betadine solution. Midline laparotomy performed with a $3 \mathrm{~cm}$ incision was the sole intervention in the laparotomy group. In the peritonitis $+\mathrm{MB}$ group, the colon was explored and incised with a scalpel. The abdomen was contaminated with the cecal content in order to induce fecal peritonitis. The defect was sutured with 4-0 polypropylene. Before closing the abdomen, MB $(1 \%, 2 \mathrm{ml})$ was applied through the suture line and abdominal viscera. In the peritonitis+saline group, the colon was explored and incised with a scalpel. The abdomen was contaminated with the cecal content in order to induce fecal peritonitis. The defect was sutured with 4-0 polypropylene. Before closing the abdomen, sterile saline solution $(2 \mathrm{ml})$ was applied through the suture line and abdominal viscera. In the colon incision + saline group, the colon was explored and incised with a scalpel. The defect was sutured with 4-0 polypropylene. Before closing the abdomen, sterile saline solution $(2 \mathrm{ml})$ was applied through the suture line and abdominal viscera. The abdomen was closed in two layers with 3-0 silk.

\section{Postoperative Evaluations}

All animals were given water only on the first postoperative day; standard rat chow and water ad libitum were provided on the second postoperative day. There was no difference in food intake between the groups. Body weight and water and food intake were monitored daily throughout the postoperative period, for up to 7 days.

On the postoperative 3rd day, 5 animals from Group I and 7 animals from Groups II, III and IV were taken for analyses. On the postoperative 7th day, 5 animals from Group I and 8 animals from Groups II, III and IV were taken for the rest of the examinations.

Mortality, morbidity, adhesion scores, histopathologic analyses, serum TNF- $\alpha$ levels and tissue 5-HP levels were evaluated in all animals. 


\section{Microbiologic Analysis}

For aerobic culture, the samples were inoculated onto 5\% sheep blood agar and MacConkey agar, and incubated for $24-48$ hours (h) at $35^{\circ} \mathrm{C}$.

\section{Adhesion Study}

A "U"-shaped laparotomy incision was made for evaluating the adhesion formation. Adhesion scores were given as mentioned before by Bothin et al. ${ }^{[19]}$ Degree, characteristics and localizations of the adhesions were evaluated. Development of intraabdominal adhesions was then assessed in animals for qualitative aspects, which were defined formerly as shown in Table 1. Each observation is given 1 point and the points are added to obtain the total score.

\section{Biochemical Analysis}

5-HP levels were measured from the sutured part of the cecum. $0.5 \mathrm{~cm}$ of the sutured part of the cecum was cleared of overlying adherent tissue and resected. The specimen was wrapped in aluminum foil, coded appropriately, frozen in liquid nitrogen, and kept at $-30^{\circ} \mathrm{C}$ for $5-\mathrm{HP}$ content determination. Biochemical studies were made as defined by Jamall et al. ${ }^{[20]}$ Briefly, the frozen tissues were dried with filter paper, weighed and divided into tiny pieces, and hydrolyzed in $6 \mathrm{~N}$ hydrochloric acid. The free 5-HP was then oxidized by chloramines to produce a pyrrole-type compound. The addition of Ehrlich's reagent resulted in the formation of chromophore with a wave length maximum at 558 $\mathrm{nm}$. These procedures yielded HP levels equivalent to nanomoles. These absolute measures were proportioned to tissue weights and the results were obtained as moles/gram tissue. ${ }^{[20]}$

Cardiac blood samples were drawn in sterile fashion for TNF- $\alpha$ measurement. Samples were kept at $-80^{\circ} \mathrm{C}$ for storage and evaluated immediately for bio-

Table 1. Cumulative adhesion scoring scale
(0) No adhesions
(1) One adhesive band from the omentum to the target organ
(1) One adhesive band from the omentum to the abdominal scar
(1) One adhesive band from the omentum to another place
(1) One adhesive band from the adnexa/epididymal fat bodies to the target organ
(1) One adhesive band from the adnexa/epididymal fat bodies to the abdominal scar
(1) One adhesive band from the adnexa/epididymal fat bodies to the another place
(1) Any adhesive band other than described above (e.g., liver to scar)
(1) Target organ adherent to the abdominal wall
(1) Target organ adherent to the abdominal scar
(1) Target organ adherent to the bowel
(1) Target organ adherent to the liver or the spleen
(1) Any other organ adherent

chemical analyses. TNF- $\alpha$ levels of serum samples were determined using the BioSource International rat TNF- $\alpha$ kit, which is a solid-phase sandwich ELISA (BioSource, USA). The minimum detectable dose of TNF- $\alpha$ is $1.7 \mathrm{pg} / \mathrm{ml}$. This was determined by adding 2 $\mathrm{SD}$ to the mean optical density obtained when the zero standard was assayed 20 times. Tissue 5-HP content and serum TNF- $\alpha$ levels were studied at Gazi University Faculty of Medicine, Department of Medical Biochemistry. ${ }^{[21]}$

\section{Histopathological Examination}

Histopathological examinations were performed by light microscopy at $\mathrm{x} 100$, and the resected tissues were fixed in formaldehyde and embedded in paraffin block, and stained with hematoxylin and eosin (H\&E). A pathologist who was blind to the groups graded the extent of fibrosis and inflammation in each specimen using a semiquantitative scoring system.

\section{Statistical Analysis}

Results of the study were statistically analyzed with NCSS 2007 \& PASS 2008 Statistical Software (Utah, USA) program. For evaluating the data, descriptive statistical methods were used with KruskalWallis test in order to analyze numeric values because of the insufficient number of the group population. When a statistical difference was obtained between groups, Mann-Whitney U test was used to confirm the difference between two groups. A statistically significant difference was accepted at a $p$ value of $<0.05$.

\section{Morbidity and Mortality}

Following the operations, all rats had symptoms of intraabdominal sepsis. They demonstrated apathetic behavior, and had ocular exudates, piloerection and diarrhea. Weight loss was observed on the 1st day. After the postoperative 1st day, rats regained weight. Differences in weight loss or weight gain were not statistically significant between the study groups. No deaths were seen in any group. Abscesses were predominantly located at the suture site. Abdominal wall suture line abscesses were seen in 5 rats in Group III and 2 rats in Group IV, while no abscesses were larger than $1 \mathrm{~cm}$.

\section{Microbiological Findings}

Culture results of the samples taken revealed polymicrobial intraabdominal infection. Frequently isolated microorganisms were Escherichia coli, Proteus species, Streptococcus, and coagulase-negative Staphylococcus.

\section{Adhesion Scores}

In all examinations, the most frequently detected adhesion formation was the adhesion of the omentum 
to the target organ. In Group II, the number of the adhesions and their characteristics were different compared to Groups III and IV (less and soft). In Group II, adhesion formation especially involved the omentum. In the 3rd day analyses, adhesion scores of Groups I, III and IV were significantly higher than in Group II $(p=0.028, p=0.05, p=0.012)$. In the 7 th day analyses, the adhesion scores of Groups III and IV were significantly higher than in Groups I and II (Table 2).

\section{Biochemical Analysis}

TNF- $\alpha$ levels were significantly higher in Groups I, III and IV in the 3 rd day analyses $(p<0.05)$. However, there was no significant difference between groups in the 7 th day analyses ( $>0.05$; Table 2$)$.

5-HP levels were significantly lower in Groups I and II compared to Groups III and IV $(p<0.05)$. The differences were significant in the $3 \mathrm{rd}$ and also 7 th day analyses (Table 2).

\section{Histopathologic Findings}

In the histopathologic examination, mild mesothelial cell proliferation, fibrosis, inflammatory cell infiltration in serosal surfaces, acute cell inflammation, and fibroblastic proliferation were seen generally. Moderate inflammation and cell infiltration with lymphoid hyperplasia were observed in Group III. Acute inflammatory reactions were dense on serosal surfaces with extensive polymorphonuclear cell infiltration in this group. Submucosal inflammatory cell infiltration and serosal microabscess formation were also seen in this group.

\section{DISCUSSION}

Complications and relaparotomies due to adhesions have been seen frequently in emergency operations for peritonitis. Colorectal surgery has a high risk of infection in a wide range from colostomies to abdomino- perineal resection. ${ }^{[22]}$ Relaparotomies due to adhesion can be seen in $19 \%$ of cases, and complications due to adhesions appear in $25 \%$ of the patients. ${ }^{[23]}$ Peritonitis seems to be the major cause of intraabdominal adhesion formation, but there are not enough experimental and clinical studies on this issue. ${ }^{[24]}$ Generalized infection in the abdominal cavity affects abdominal tissues in relation to operative materials and fluids. While results of some materials tested in the prevention of adhesion formation were reported in a limited number of studies in the literature, an ideal material has yet to be identified.

Adhesion formation is a dynamic and complex process, which can be triggered by any peritoneal injury and even through a controlled injury, such as surgery. It involves a cascade of cellular, biochemical and immunological factors. ${ }^{[25]}$ Inflammatory cellular activity in mesothelial regeneration and the alteration of the peritoneal fibrinolytic system are considered as the main pathways of adhesion formation. ${ }^{[25]}$

According to our findings, $\mathrm{MB}$ application reduces adhesion formation after peritonitis based on alterations determined in adhesion scores, whereas it impairs wound healing as depicted by reduction in serum TNF- $\alpha$ and tissue 5-HP levels.

MB was reported to cause a significant impairment in the early phases of wound healing. ${ }^{[18]}$ In addition, as demonstrated experimentally, ${ }^{[10]} \mathrm{MB}$ has been reported to inhibit generation of oxygen radicals, such as superoxide, by competing with the molecular oxygen for the transfer of electrons from xanthine oxidase. ${ }^{[18]}$ Although the antiadhesive effect of MB has been associated with its antioxidant properties, increased peritoneal fibrinolytic activity was also documented to have a role in subsequent degradation of nascent adhesions. ${ }^{[17]}$

Table 2. 5-HP and TNF- $\alpha$ levels and adhesion scores in the experimental groups on the postoperative 3rd and 7 th days

\begin{tabular}{|c|c|c|c|c|c|}
\hline & $\begin{array}{c}\text { Group I } \\
\text { (Laparotomy) }\end{array}$ & $\begin{array}{c}\text { Group II } \\
(\mathrm{MB}+\text { Peritonitis })\end{array}$ & $\begin{array}{c}\text { Group III } \\
\text { (Peritonitis }+ \text { Saline })\end{array}$ & $\begin{array}{c}\text { Group IV } \\
\text { (Colitis + Saline })\end{array}$ & $\dagger p$ \\
\hline 5-HP levels & Mean \pm SD & Mean \pm SD & Mean \pm SD & Mean \pm SD & \\
\hline Postop. day 3 & $15.16 \pm 1.04$ & $5.62 \pm 0.5$ & $9.27 \pm 2.73$ & $14.97 \pm 0.22$ & 0.02 \\
\hline Postop. day 7 & $16.92 \pm 1.05$ & $5.68 \pm 0.43$ & $8.36 \pm 1.88$ & $18.04 \pm 3.98$ & 0.03 \\
\hline$\# p$ value & 0.248 & 0.697 & 1.0 & 0.021 & \\
\hline \multicolumn{6}{|l|}{ TNF- $\alpha$ levels } \\
\hline Postop. day 3 & $28.49 \pm 8.33$ & $1.18 \pm 0.04$ & $131.04 \pm 28.14$ & $125.4 \pm 35.21$ & 0.009 \\
\hline Postop. day 7 & $46.01 \pm 18.1$ & $20.18 \pm 4.9$ & $72.92 \pm 17.0$ & $52.52 \pm 16.14$ & 0.49 \\
\hline$\# \mathrm{p}$ value & 0.276 & 0.465 & 1.0 & 0.541 & \\
\hline \multicolumn{6}{|c|}{ Adhesion scores } \\
\hline Postop. day 3 & $0.4 \pm 0.14$ & $1.75 \pm 0.16$ & $6.5 \pm 1.29$ & $4.0 \pm 0.81$ & 0.001 \\
\hline Postop. day 7 & $0.6 \pm 0.14$ & $1.71 \pm 0.35$ & $5.12 \pm 1.41$ & $4.36 \pm 1.5$ & 0.001 \\
\hline$\# p$ value & 0.375 & 0.948 & 0.549 & 0.504 & \\
\hline
\end{tabular}

$\dagger$ Kruskal-Wallis Test; \# Mann-Whitney U Test. 
Subsequent to the acute inflammation of the peritoneum in response to trauma, there is an influx of cells, mainly macrophages, by chemotactic mechanisms. These macrophages, when activated again by plasmin, produce interleukin (IL)-1 and TNF- $\alpha$, important factors in wound healing. ${ }^{[26]}$ In line with these statements, TNF- $\alpha$ levels were significantly lower in the MB group on the 3rd day examinations, indicating impairment in wound healing. Furthermore, based on the well-known correlation between tensile strength of the wound and its 5-HP content, the significant reduction obtained in tissue HP levels postoperatively seems also to be responsible for the delayed wound healing in our rats.

Whether resulting from its antioxidant or fibrinolytic effect, the antiadhesive properties of MB have been documented to be dose-dependent, with increased efficacy at its lower doses. ${ }^{[27]}$

In conclusion, while MB seems to prevent peritoneal adhesions in a rat peritonitis model, wound healing could be impaired concomitantly. MB should be further evaluated because of its dual effect.

\section{REFERENCES}

1. Sahin Y, Saglam A. Synergistic effects of carboxymethylcellulose and low molecular weight heparin in reducing adhesion formation in the rat uterine horn model. Acta Obstet Gynecol Scand 1994;73:70-3.

2. Thompson JN, Whawell SA. Pathogenesis and prevention of adhesion formation. Br J Surg 1995;82:3-5.

3. Mirastschijski U, Johannesson K, Jeppsson B, Agren MS. Effect of a matrix metalloproteinase activity and TNF-alpha converting enzyme inhibitor on intra-abdominal adhesions. Eur Surg Res 2005;37:68-75.

4. Wilson MS. Practicalities and costs of adhesions. Colorectal Disesase 2005; 7:551-8.

5. Van Der Krabben AA, Dijkstra FR, Nieuwenhuijzen M, Reijnen MM, Schaapveld M, Van Goor H. Morbidity and mortality of inadvertent enterotomy during adhesiotomy. $\mathrm{Br}$ J Surg 2000;87(4):467-71.

6. Hutchins RR, Gunning MP, Lucas DN, Allen-Mersh TG, Soni NC. Relaparotomy for suspected intraperitoneal sepsis after abdominal surgery. World J Surg 2004;28:137-41.

7. Ellis H. Internal overhealing: the problem of intraperitoneal adhesions. World J Surg 1980;4:303-6.

8. Fabri PJ, Rosemurgy A. Reoperation for small intestinal obstruction. Surg Clin North Am 1991;71:131-46.

9. Bedirli A, Gokahmetoglu S, Sakrak O, Ersoz N, Ayangil D, Esin H. Prevention of intraperitoneal adhesion formation using beta-glucan after ileocolic anastomosis in a rat bacterial peritonitis model. Am J Surg 2003;185:339-43.

10. Galili Y, Ben-Abraham R, Rabau M, Klausner J, Kluger Y. Reduction of surgery-induced peritoneal adhesions by methylene blue. Am J Surg 1998;175:30-2.
11. Ezberci F, Bulbuloglu E, Ciragil P, Gul M, Kurutas EB, Bozkurt $\mathrm{S}$, et al. Intraperitoneal tenoxicam to prevent abdominal adhesion formation in a rat peritonitis model. Surg Today 2006;36:361-6.

12. Ara C, Karabulut AB, Kirimlioglu H, Yilmaz M, Kirimliglu V, Yilmaz S. Protective effect of aminoguanidine against oxidative stress in an experimental peritoneal adhesion model in rats. Cell Biochem Funct 2006;24:443-8.

13. Sikkink CJ, de Man B, Bleichrodt RP, van Goor H. Autocross-linked hyaluronic acid gel does not reduce intra-abdominal adhesions or abscess formation in a rat model of peritonitis. J Surg Res 2006;136:255-9.

14. Müller SA, Treutner KH, Haase G, Kinzel S, Tietze L, Schumpelick V. Effect of intraperitoneal antiadhesive fluids in a rat peritonitis model. Arch Surg 2003;138:286-90.

15. Steinberg J, Halter J, Schiller HJ, Dasilva M, Landas S, Gatto LA, et al. Metalloproteinase inhibition reduces lung injury and improves survival after cecal ligation and puncture in rats. J Surg Res 2003;111:185-95.

16. Galili Y, Kluger Y, Mianski Z, Iaina A, Wollman Y, Marmur S, et al. Methylene blue--a promising treatment modality in sepsis induced by bowel perforation. Eur Surg Res 1997;29:390-5.

17. Heydrick SJ, Reed KL, Cohen PA, Aarons CB, Gower AC, Becker JM, et al. Intraperitoneal administration of methylene blue attenuates oxidative stress, increases peritoneal fibrinolysis, and inhibits intraabdominal adhesion formation. J Surg Res 2007;143:311-9.

18. Dinc S, Ozaslan C, Kuru B, Karaca S, Ustun H, Alagol H, et al. Methylene blue prevents surgery-induced peritoneal adhesions but impairs the early phase of anastomotic wound healing. Can J Surg 2006;49(5):321-8.

19. Bothin C, Okada M, Midtvedt T, Perbeck L. The intestinal flora influences adhesion formation around surgical anastomoses. Br J Surg 2001;88:143-5.

20. Jamall IS, Finelli VN, Que Hee SS. A simple method to determine nanogram levels of 4-hydroxyproline in biological tissues. Anal Biochem 1981;112:70-5.

21. Engelberts I, Möller A, Schoen GJ, van der Linden CJ, Buurman WA. Evaluation of measurement of human TNF in plasma by ELISA. Lymphokine Cytokine Res 1991;10:69-76.

22. Parker MC, Wilson MS, Menzies D, Sunderland G, Thompson JN, Clark DN, et al. Colorectal surgery: the risk and burden of adhesion-related complications. Colorectal Dis 2004;6:506-11.

23. Stanciu D, Menzies D. The magnitude of adhesion-related problems. Colorectal Dis 2007;9:35-8.

24. Müller SA, Treutner KH, Haase G, Kinzel S, Tietze L, Schumpelick V. Effect of intraperitoneal antiadhesive fluids in a rat peritonitis model. Arch Surg 2003;138:286-90.

25. Duron JJ. Postoperative intraperitoneal adhesion pathophysiology. Colorectal Dis 2007;9:14-24.

26. van der Wal JB, Jeekel J. Biology of the peritoneum in normal homeostasis and after surgical trauma. Colorectal Dis 2007;9:9-13.

27. Raşa K, Erverdi N, Karabulut Z, Renda N, Korkmaz A. The effect of methylene blue on peritoneal adhesion formation. Turk J Gastroenterol 2002;13:108-11. 